\title{
CAN NALOXONE INHIBIT THE CARDIOVASCULAR EFFECT OF ACUPUNCTURE?
}

\author{
D.C. LeE, K. Ichiyanagi*, M.O. Lee, D. H. Clifford and L.E. Morris
}

ACupuncture, or the stimulation of acupuncture loci, has been demonstrated to be effective in treating various types of pain. ${ }^{1-7}$ It also acts on the autonomic nervous system and acupuncture at Jen Chung (Go-26) and Tsu San $\mathrm{Li}$ (St-36) produce sympathomimetic and parasympathomimetic effects respectively on the cardiovascular system..$^{8,9}$ The sympathomimetic effects can be blocked by a beta blocker, propranolol, or to a lesser extent, an alpha blocker, phentolamine, while the parasympathomimetic effects can be inhibited by atropine. 10-12

Acupuncture appears to cause the release of enkephalins from their storage sites in the brain. ${ }^{13-16}$ The enkephalins have a morphinelike or pain relieving effect and can be inhibited by the narcotic antagonist naloxone. ${ }^{17.18}$ The purpose of this investigation is to determine if naloxone will inhibit the sympathomimetic effect on the cardiovascular system of one form of acupuncture, moxibustion by electrocautery at Jen Chung (Go-26).

\section{Methods and Materials}

Forty experiments were performed on healthy mongrel dogs weighing from 11.5 to $20 \mathrm{~kg}$. An electromagnetic flow probet was implanted around the ascending aorta as previously described $^{\mathrm{s}}$ and the dogs were observed for approximately ten days to ensure that the probes were well tolerated. Anaesthesia was induced with thiopentone $15 \mathrm{mg} \cdot \mathrm{kg}^{-1}$ and the trachea was intubated. Anaesthesia was maintained with an inspired concentration of 0.75 per cent halothane in oxygen delivered from a copper kettle vaporizer. Apnoea was maintained by an in-

Supported in part by BRS Grant No. 5-SO1-RR05700-06 (N.I.H.) and the Northwestern Ohio Heart Association. From the Departments of Anesthesia. Physiology and Anatomy and the Division of Labora1ory Animal Medicine. Medical College of Ohio, C.S. \# 10008, Toledo. Ohio 43699, U.S.A.

*Department of Anesthesia. School of Medicine. Yamagata University, Yamagata, Japan.

$\Varangle$ Zepeda non-ferrous electromagnetic flow probe. Zepeda Instruments. 1937, 25th Ave. E., Seattle, Washington 98112 , U.S.A.

410

Canad. Anaesth. Soc. J., vol. 26, no. 5, September 1979 travenous drip of succinylcholine $(1.0 \mathrm{mg} / \mathrm{ml})$ in isotonic saline and the lungs were ventilated mechanically with a Harvard animal sespirator set to maintain the $\mathrm{PaCO}_{2}$ at $5.32 \pm 0.27$ kPa (40 \pm 2 torr). Halothane 0.75 per cent with a succinylcholine drip produced reliable immobilization and permitted mechanical ventilation without depressing the autonomic nervous system. Aortic flow was measured by the chronically implanted electromagnetic flow probe. The aurtic flow wave was recorded and an integral of this wave form was triggered by the QRS complex of the electrocardiogram to obtain a measure of stroke volume for each heart beat. This procedure has also been described." vein was cannulated for the injection of succinylcholine and the femoral artery was cannulated for continous monitoring of blood pressure through a Statham pressure transducer (P23AA). It was also used for the anaerobic sampling of arlerial blood for the determination of $\mathrm{pH}, \mathrm{Pa}_{\mathrm{O}_{2}}$ and $\mathrm{Pa}_{\mathrm{CO}_{2}} .{ }^{9-11}$ The heart rate was counted from the electrocardiogram.

Measurements of the haemodynamic parameters were made every five minutes for the first 30 minutes and every 15 minutes for the ensuing 90 minutes with an Offner type RB dynograph. Control values for each animal were determined by the average of two measurements taken 15 and 30 minutes before the administration of naloxone and/or moxibustion with electrocautery at the Go-26 locus. Thus each animal served as its own control, which is expressed as 0 . Oesophageal temperature was maintained at $37 \pm 1^{\circ} \mathrm{C}$. as measured with a thermister probe and Yellow Springs telethermometer. A Godart capnograph was used to provide continual visual evidence that end-tidal carbon dioxide was at a normal level.

The acupuncture point Jen Chung (Go-26), which is at the midpoint of the philtrum, was located by the cutaneous impedance equipment, Acutest.* Moxibustion by electrocautery produces a very strong stimulus. The electrocautery

*The Aculest, designed by one of the authors, D.C.L., measures resislance of the skin to a 6 volt, 100 microampere current. 
Moxistimulator. ${ }^{\dagger}$ maintained the $3 \mathrm{~mm}$ diameter probe at $80 \pm 5^{\circ} \mathrm{C}$ and was applied for ten $\mathrm{mi}-$ nutes. The same procedures were followed for neutral sites which were a few millimeters from the acupuncture point. The neutral sites are areas adjacent to Jen Chung (Go-26) where cutaneous resistance is high, allowing passage of a current of 12 microamperes, while resistance is decreased permitting passage of a current of 60 microamperes or more at acupuncture points. Naloxone $1 \mathrm{mg} \cdot \mathbf{k g}^{-1}$ was administered intravenously about two minutes before moxibustion.

\section{RESULTS}

Measurement of the following cardiovascular variables were made during the 120 minutes of observation: (1) cardiac output, (2) stroke volume, (3) heart rate, (4) mean arterial pressure, (5) pulse pressure, (6) central venous pressure, (7) total peripheral resistance and $(8)$ acid-base and blood gases. Student's " $t$ " test was used to compare values for each parameter with its control. When values at two time-intervals were significant (five per cent level), the change was considered meaningful. The first seven parameters listed above are compared graphically (Figures 1-7). $\mathrm{Pa}_{\mathrm{O}_{2}}, \mathrm{pH}, \mathrm{Pa}_{\mathrm{CO}_{2}}$ and base deficit did not change significantly. Since the $\mathrm{Paco}_{2}$ was maintained at $5.32 \pm 0.27 \mathrm{kPa}(40 \pm 2$ torr $)$, it is not included.

\section{Cardiac Output and Mean Arterial Pressure}

Cardiac output and mean arterial pressure were significantly increased after moxibustion alone at Jen Chung (Go-26), naloxone followed by moxibustion at Go-26 and naloxone alone (Figures 1 and 4). Significant changes were not observed in anaesthetized animals under halothane anaesthesia without intervention, or in those stimulated at a neutral point adjacent to Jen Chung (Go-26).

\section{Stroke volume}

Significant increases in stroke volume were observed following moxibustion with electrocautery at Jen Chung (Go-26) (Figure 2). No consistent changes were observed in the four other groups.

\section{Heart rate and pulse pressure}

Significant increases in heart rate and pulse

The Moxibustimulator, designed by one of the authors, D.C.L., is calibrated so that readings between 300 and 400 milliamps produce $80 \pm 5^{\circ} \mathrm{C}$ in the probe.

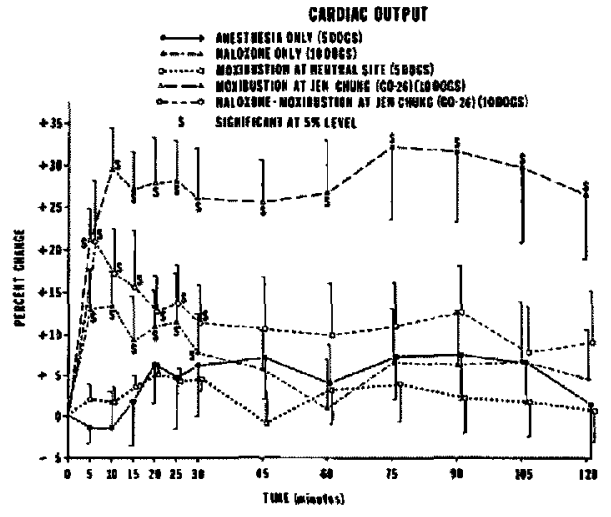

Figure I Effect of naloxone and/or acupuncturemoxibustion at Jen Chung (Go-26) on the cardiac output of dogs under halothane anaesthesia. The cardiac output is plotted as per cent change from 0 , which is the average of two values taken before stimulation or administration of naloxone. One control group consisted of animals maintained under halothane anaesthesia alone and another in which acupuncture-moxibustion was done at a neutral site.

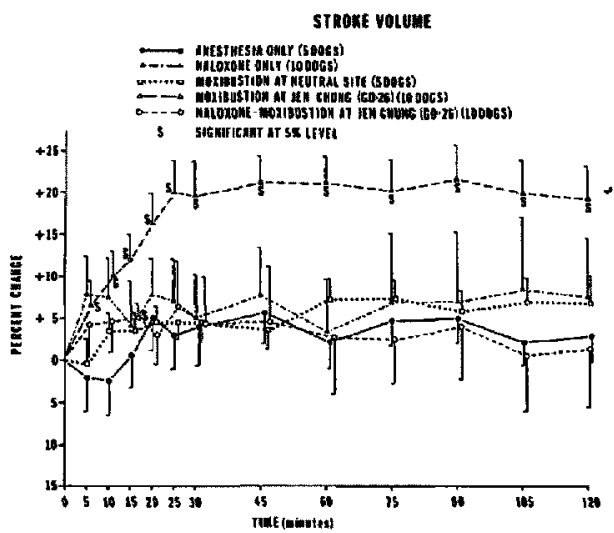

FIGURE 2 Effect of naloxone and/or acupuncturemoxibustion at Jen-Chung (Go-26) on the stroke volume of dogs under halothane anaesthesia. The stroke volume is plotted as per cent change from 0 , which is the average of two values taken before stimulation or administration of naloxone. One control group consisted of animals maintained under halothane anaesthesia alone and another in which acupuncture-moxibustion was done at a neutral site.

pressure were observed in the groups which received moxibustion alone and naloxone before moxibustion (Figures 3 and \$). Changes in the three other groups, that is anaesthesia alone, moxibustion at a neutral point, or naloxone alone, were not significant. 


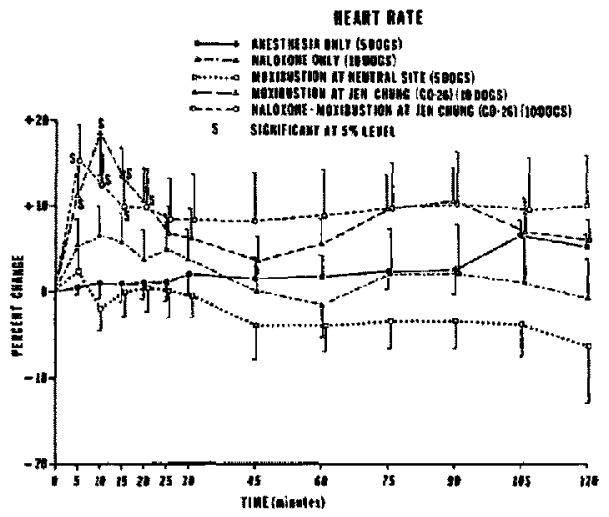

Figurt. 3 Effect of naloxone and/or acupuncturemoxibustion at Jen-Chung (Go-26) on the heart rate of dogs under halothane anaesthesia. The heart rate is ploted as per cent change from 0 . which is the average of two values taken before stimulation or administration of naloxune. One control group consisted of animals maintained under halothane anaesthesia alone and another in which acupuncture-moxibustion was done at a neutral site.

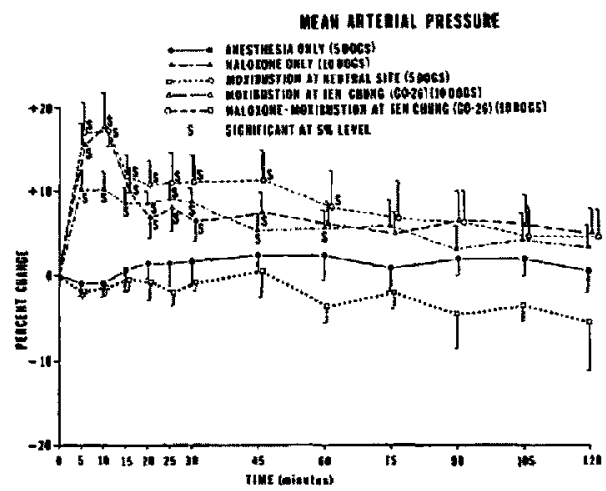

FIGURE 4 Effect of naloxone and/or acupuncturemoxibustion at Jen-Chung $(\mathrm{Ga}-26)$ on the mean arterial pressure of dogs under halothane anaesthesia. The mean arterial pressure is plotted as per cent change from 0 . which is the average of two values taken before stimulation or administration of naloxone. One contrul group consisted of animals maintain ed under halothane anaesthesia alone and another in which acupuncturemoxibustion was done at a neutral site.

\section{Central venous pressure}

Central venous pressure was significantly increased in the group in which naloxone was administered before moxibustion (Figure 6). Naloxone alone produced marked but not significant increases in pulse pressure.

\section{Total peripheral resistance}

A significant decrease in total peripheral resistance was observed following moxibustion at Jen Chung (Go-26) (Figure 7). Anaesthesia alone. moxibustion at a neutral site and naloxone preceding moxibution did not produce significant changes.

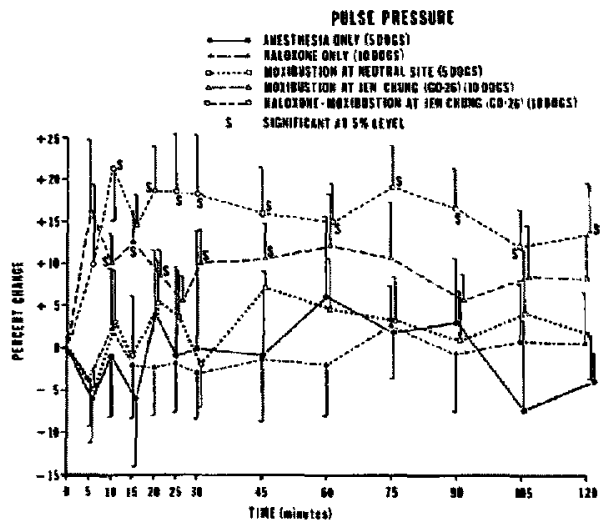

FigURE 5 Effect of naloxone ind/or acupuncturemoxibustion at Jen Chung (Go-26) on the pulse pressure of dogs under halothane anaesthesia. The pulse pressure is plotted as per cent change from 0 . which is the average of two values taken before stimulation or administration of naloxone. One control group consisted of animals maintained under halothane anaesthesia alone and another in which acupuncture-moxibustion was done at a neutral site.

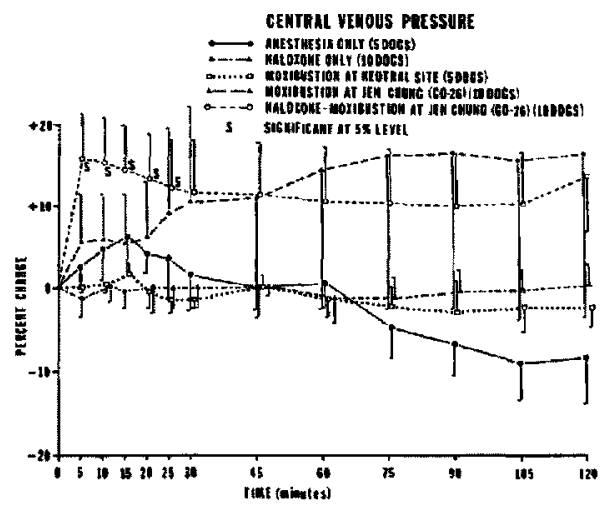

Figure 6 Effect of naloxone and/or acupuncturemoxibustion at Jen Chung (Go-26) on the central venous pressure of dogs under halothane anaesthesia. The central venous pressure is plotted as per cent change from 0 , which is the average of two values taken before stimulation or administration of naloxone. One control group consisted of animals maintained under halothane anaesthesia alone and another in which acupuncture moxibustion was done at a neutral site. 
TOTAL PERIPHERA ECsIstnuce

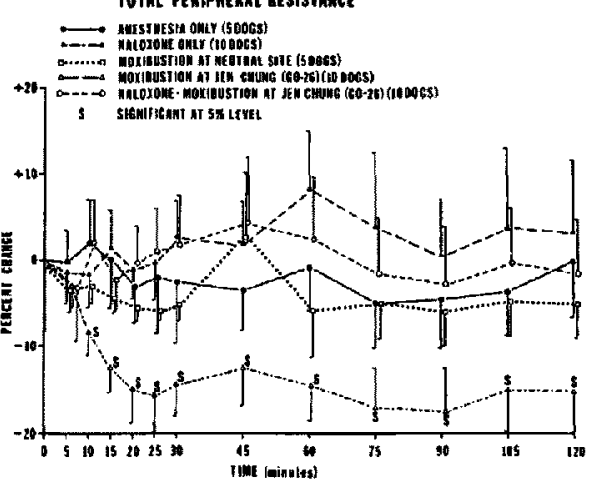

FIGURE 7 Effect of naloxone and/or acupuncturemoxibustion at Jen Chung (Go-26) on the total peripheral resistance of dogs under halothane anaesthesia. The total peripheral resistance is plotted as per cent change from 0 , which is the average of two values taken before stimulation or administration of naloxone. One control group consisted of animals maintained under halothane anaesthesia alone and another in which acupuncture-moxibustion was done.

\section{Discussion}

The isolation from the brain of polypeptides simulating the effects of morphine ${ }^{14-16.19}$ and observation that these substances are found in highest concentration where electrical stimulation produces its effect ${ }^{21.22}$ were important in establishing a basis for the use of acupuncture in the treatment of pain. Subsequently. it was found that naloxone. a narcotic antagonist, inhibited the analgesic effect of acupuncture. ${ }^{17.23}$

The administration of narcotic antagonists such as nalorphine is associated with respiratory depression. lowering the body temperature. decrease in heart rate and constriction of the pupils. ${ }^{24}$ The cardiovascular effects of nalorphine, which are decrease in heart rate and cardiac output and similar to those of morphine, are due to medullary vasomotor depression ${ }^{25}$ and not to elevation of $\mathrm{Pa}_{\mathrm{CO}_{2}}$, since moderate hypercapnia causes an increase in cardiac output and mean arterial pressure. Naloxone produces less respiratory depression than nalorphine or levallorphan and is a more specific narcotic antagonist, since it does not exhibit a morphinomimetic effect. ${ }^{25.26}$ It does not appear to inhibit the respiratory center response to hypercapnia. This enables moderate hypercapnia to increase cardiac output, heart rate and mean arterial pressure.

Acupuncture is well known for its role in the treatment of pain, although the sympathomimetic and parasympathomimetic effects may be equally important. It was demonstrated in earlier studies that propranolol and, to a lesser extent, phentolamine, were capable of inhibiting the sympathomimetic effect of acupuncture at Jen Chung (Go-26) on the cardiovascular systems. ${ }^{8.10 .11}$ The obvious question is whether naloxone inhibits the autonomic actions of acupuncture. This study indicates that the polypeptide neurotransmitters associated with pain do not play a major role in mediating the autonomic effects of acupuncture.

\section{SUMMARY}

Forty dogs were studied during MAC-1 halothane anaesthesia with a chronically implanted electromagnetic flow probe on the ascending aorta. Cardiac output, stroke volume. heart rate, mean arterial pressure, pulse pressure, central venous pressure and total peripheral resistance were determined in addition to $\mathrm{Pa}_{\mathrm{H}_{2}}$. $\mathrm{pH}, \mathrm{Pa}_{\mathrm{CO}_{2}}$ and base deficit.

Acupuncture moxibustion with electrocautery at Jen Chung ( $\mathrm{Go}-26$ ) produced a significant (five per cent level) increase in the cardiac output, stroke volume, heart rate, mean arterial pressure and pulse pressure and a significant decrease in total peripheral resistance during a 120-minute period of observation in dogs under halothane anaesthesia. Acupuncture moxibustion at Go-26 following pretreatment with the narcotic antagonist naloxone ( $\mathrm{mg} \cdot \mathrm{kg}^{-1}$ ) produced a significant increase in cardiac output. heart rate, mean arterial pressure, pulse pressure and central venous pressure. It is concluded that naloxone, which inhibits the analgesic effects of acupuncture, does not inhibit the sympathomimetic effect of acupuncture or moxibustion at Jen Chung (Go-26) in dogs under light MAC-I halothane anaesthesia.

\section{RÉSUMÉ}

L'étude porte sur 40 chiens anesthésiés à l'halothane (MAC-1) porteurs de débitmètres électromagnétiques implantés dans l'aorte ascendante. Le débit cardiaque, le volume d’éjection, la fréquence cardiaque, la pression artérielle moyenne et différentielle, la tension veineuse centrale, la résistance périphẻrique totale ont été déterminés ainsi que la $\mathrm{Pa}_{\mathrm{O}_{2}}$, le $\mathrm{pH}$, la $\mathrm{Pa}_{\mathrm{CO}}$ et le déficit de base.

La moxibustion associée à l'acupuncture obtenues par électrocautérisation du point Jen Chung (Go-26) a produit une augmentation 
significative de l'ordre de cinq pour cent de tous les paramètres vasculaires, à l'exception de la résistance périphérique totale qui a subis une baisse significative pendant la période d'observation de 120 minutes des chiens anesthésiés à I'halothane. L'acupuncture-moxibustion au point Go-26 après traitement préalable à l'antagoniste narcotique naloxone ( $\mathbf{~} \mathrm{mg} \cdot \mathbf{k g}^{-1}$ ) a été suivie d'une augmentation significative du débit cardiaque, de la fréquence, de la pression artérielle moyenne et différentielle ainsi que de la pression veineuse centrale. On en conclut que la naloxone qui inhibe les effets analgésiques de l'acupuncture, ne cause pas d'inhibition des effets sympathycomimétiques de l'acupuncture ou de la moxibustion à Jen Chung (Go-26) chez les chiens anesthésiés légèrement à l'halothane (MAC-1).

\section{ACKNOWLEDGEMENTS}

The authors wish to thank Messrs. Thomas Tenney. M.S., P.E., and Jeff Shall for technical assistance; Miss Carol Perkins and Mr. Gerald Lubinski for aid with the illustrations; Mrs. Patti Murphy and Mrs. Gerry Burton for aid in preparing the manuscript.

The halothane (Fluothane $\left.{ }^{(}\right)$was furnished by Ayerst Laboratories and the naloxone hydrochloride was supplied by Endo Laboratories, Inc.

\section{REFERENCES}

1. Andersson, S.A., Ericson, T., Holmoren, E. \& LINDGRIST, G. Electro-acupuncture. Effect on pain threshold measured with electrical stimulation of teeth. Brain Res. 63: 393 (1973).

2. Leung, S.J., Fan, C.F. \& Sechzer, P.H. Acupuncture therapeutics. Anaesth. Analg. (Cleve) 53: 942 (1974).

3. ManN, F. Bowsher, D., Mumford, J., Lipton, S. \& MILES, J. Treatment of intractable pain by acupuncture. Lancet 2: 57 (1973).

4. Nemerof, H. Clinical experiences with acupuneture. J. Am. Osteopath. Assoc. 71: 866 (1972).

5. Peng, A.T.C., Omura, Y., Cheng, H.C. \& Blancato, L.S. Acupuncture for relief of chronic pain and surgical analgesia. Am. Surg. 40: 50 (1974).

6. Spoerel, W.E. \& Leuna, C.Y. Acupuncture in a pain dinic. Can. Anaesth. Soc. J. 21: 221 (1974)

7. Wallis, L., SNyder, S.M., Palahniuk, R.J. \& SPIVEY, H.T. An evaluation of acupuncture analgesia in obstetrics. Anesthesiology 4l: 596 (1974).

8. Lee, D.C., LeE, M.O. \& Clifford, D.H. Cardiovascular effects of moxibustion at Jen Chung
(Go-26) during halothane anesthesia in dogs. Am. J. Chinese Med. 3; 245 (1975).

9. LeE, M.O.. LeE, D.C. KIM, S. \& Clifford, D.H. Cardiovascular effects of acupuncture at Tsil San $\mathrm{Li}(\mathrm{St}-36)$ in dogs. J. Surg. Res. 18: $\mathrm{SI}$ (1975).

10. LEE, D.C. LEE, M.O. ClIFFORD, D.H \& MORRis, L. E. Inhibition of the cardiovascular effects of acupuncture (moxibustion) by propranolol in dogs during halothane anesthesia. Can. Anaesth. Soc. J. 23: 307 (1976).

11. LeE, M.O., LEe, D.C. \& CLIFFord, D.H. Inhibition of the cardiovascular effects on acupuncture (moxibustion) by phentolamine in dogs during halothane anesthesia. Am. J. Chinese Med. 4: 153 (1976).

12. Clifford, D.H. LeE, M.O \& LeE, D.C. Cardiovascular effects of atropine on acupuncture. needling with electrostimulation, at Tsu San $\mathrm{Li}$ (St-36) in dogs. Am. J, Vet. Res, 38: 845 (1977).

13. COX, B.M., OPhEIM, K.E., Teschemacher, H. \& Goldstein, A. A peptide-like substance from pituitary that acts like morphine. 2. Purification and properties. Life Sci. 16: 1777 (1975).

14. Hughes, J. Isolation of an endogenous compound from the brain with pharmacological properties similar to morphine. Brain Res. 88: 295 (1975).

15. Teschenmacher, H., Opheim, K.E. CoX, B.M. \& Goldstein, A. A peptide-like substance from pituitary that acts like morphine. I. Isolation. Life Sci. 16: 1771 (1975).

16. Ross, M., Dingledine, R.. Cox, B.M. \& Goldstean, A. Distribution of endorphins (Peptides with morphine-like pharmacological activity in pituitary). Brain Res. 124: 523 (1977).

17. Mayer, D.J., Phice, D.D. \& Raffil. A. Antagonism of acupuncture analgesia in man by the narcotic antagonist naloxone. Brain Res. 121: 368 (1977).

18. Pomeranz, B., Cheng, R. \& law, P. Acupuncture reduces electrophysiological and behavioral responses to noxious stimuli: Pituitary is implicated. Exp. Neurol. 54: 172 (1977).

19. PERT, A. \& YAKsh, T. Sites of morphine-induced analgesia in the primate brain: Relation to brain pathways. Brain Res. 80: 135 (1974)

20. Terenius. L. \& Wahlstrom. A. Morphine-like ligand for opiate receptors in human CSF. Life Sci. 16: $1759(1975)$.

21. HuGHES.J. Search for the endogenous ligand of the opiate receptor. Neurosei. Res. Program Bull 13: 55 (1975).

22. SNyder, S.H. The brain's own opiates. Chem. \& Engineering News 55: 26 (1977).

23. Pomeranz, B. \& Chiu, D. Naloxone blockade of acupuncture analgesia: endophin implicated. Life Sci. 19: 1757 (1976)

24. Goodman, L.S. \& Gilman, A. The Pharmacological Basis of Therapeutics, 4 th Ed.. The Macmillan Co., New York, N.Y. (1970).

25. Meyers, F.h., Jawets, E. G Goldfien, A. Review of Medical Pharmacology, Lange Medical Publication, Los Altos. California (1976).

26. CONN, Howard, F. Current Therapy, W.B. Saunders Company, Philadelphia (1973). 